\title{
Can Homeopathy Bring Additional Benefits to Thalassemic Patients on Hydroxyurea Therapy? Encouraging Results of a Preliminary Study
}

\author{
Antara Banerjee ${ }^{1}$, Sudipa Basu Chakrabarty², Susanta Roy Karmakar', \\ Amit Chakrabarty ${ }^{2}$, Surjyo Jyoti Biswas ${ }^{1}$, Saiful Haque ${ }^{1}$, Debarsi Das ${ }^{1}$, Saili Paul ${ }^{1}$, \\ Biswapati Mandal ${ }^{3}$, Boujedaini Naoual ${ }^{4}$, Philippe Belon ${ }^{4}$ and \\ Anisur Rahman Khuda-Bukhsh ${ }^{1}$
}

${ }^{1}$ Cytogenetics and Molecular Biology Laboratory, Department of Zoology, University of Kalyani, Kalyani-741 235, ${ }^{2}$ Institute of Genetic Engineering, 30 Thakurhat Road, Badu, Kolkata-700 128, ${ }^{3}$ Directorate of Research, Bidhan Chandra Krishi Viswavidyalaya, Kalyani, West Bengal, India and ${ }^{4}$ Boiron Laboratory, 20 Rue de la Liberation, Sainte-Foy-Les-Lyon, France

\begin{abstract}
Several homeopathic remedies, namely, Pulsatilla Nigricans (30th potency), Ceanothus Americanus (both mother tincture and 6th potency) and Ferrum Metallicum (30th potency) selected as per similia principles were administered to 38 thalassemic patients receiving Hydroxyurea (HU) therapy for a varying period of time. Levels of serum ferritin (SF), fetal hemoglobin $(\mathrm{HbF})$, hemoglobin $(\mathrm{Hb})$, platelet count $(\mathrm{PC})$, mean corpuscular volume (MCV), mean corpuscular hemoglobin concentration $(\mathrm{MCHC})$, mean corpuscular hemoglobin $(\mathrm{MCH})$, white blood cell (WBC) count, bilirubin content, alanine amino transferase (ALT), aspartate amino transferase (AST) and serum total protein content of patients were determined before and 3 months after administration of the homeopathic remedies in combination with $\mathrm{HU}$ to evaluate additional benefits, if any, derived by the homeopathic remedies, by comparing the data with those of 38 subjects receiving only HU therapy. Preliminary results indicated that there was a significant decrease in the SF and increase in $\mathrm{HbF}$ levels in the combined, treated subjects. Although the changes in other parameters were not so significant, there was a significant decrease in size of spleen in most patients with spleenomegaly and improvement in general health conditions along with an increased gap between transfusions in most patients receiving the combined homeopathic treatment. The homeopathic remedies being inexpensive and without any known side-effects seem to have great potentials in bringing additional benefits to thalassemic patients; particularly in the developing world where blood transfusions suffer from inadequate screening and fall short of the stringent safety standards followed in the developed countries. Further independent studies are encouraged.
\end{abstract}

Keywords: Ceanothus Americanus-ferritin-Ferrum Metallicum-fetal hemoglobinhomeopathic remedy - Hydroxyurea-Pulsatilla Nigricans - Thalassemia

For reprints and all correspondence: Prof. Anisur Rahman KhudaBukhsh, Cytogenetics and Molecular Biology Laboratory, Department of Zoology, University of Kalyani, Kalyani-741 235, West Bengal, India. E-mail: khudabukhsh_48@rediffmail.com

\section{Introduction}

Thalassemia is a hereditary anemia resulting from defects in hemoglobin production. It is among the most common genetic disorders worldwide. About $4.83 \%$ of the world's 
population is carrying globin variants, including $1.67 \%$ of the population that is heterozygous for $\alpha$-thalassemia and $\beta$-thalassemia (1). In $\beta$-thalassemic patients, there is a decrease in the production of $\beta$-globin chains, as a consequence of which multiple organs get affected (2) and considerable mortality results. In $\mathrm{HbE} / \beta$-thalassemia, there is a mutation on both genes for the synthesis of $\beta$-chain in adult and hemoglobin $\mathrm{E}$ meant for synthesis of embryonic hemoglobin. Thalassemia is caused by any of more than 200 point mutations and rarely by deletions (3). It is clinically heterogeneous because various genetic lesions variably impair globin chain synthesis. The anemia associated with thalassemia may be moderate to severe depending on the gene mutations involved. Severe anemia is generally accompanied by ineffective erythropoiesis, with bone expansion and extra medullary hematopoiesis in the liver and spleen (also at other sites) generally resulting in enlarged liver and spleen. Transfusion therapy is considered the main stay of treatment when the patients become anemic beyond a threshold with all typical sufferings of thalassemia, and treatment by the usual chelation therapy is no more effective.

However, transfusion-related infections (primarily Hepatitis B and C, or HIV) are now considered the major cause of death in developing countries where proper blood testing facility is not available. Although regular transfusion therapy can help maintain growth and development and also reduces hepato-spleenomegaly due to extra medullary hematopoiesis, transfusion therapy is often taken as the last resort in the developing countries, partly for economic reasons and partly for lack of infra-structural facilities. Therefore, iron chelation therapy occupies a pivotal place in the control and management of thalassemia, because this therapy is reported to double the life expectancy of patients with thalassemia major $(4,5)$. Of the different chelators, Deferiprone, Deferoxamine, etc., are regularly used, although they have been reported to have considerable side effects and they are generally more costly (6-10), precluding their use to a large extent by poor patients. However, a number of new oral chelators like Deferasirox (ICL 670) are presently under development (11).

It is well established that affected patients do not become anemic until the fetal (gamma) globin genes are developmentally silenced, and that patients with persistent high levels of fetal globin typically have less severe anemia, have milder clinical syndromes and are often transfusion independent (12). Therefore, another approach through augmenting the synthesis of fetal hemoglobin has been made by using drugs like 5-Azacitidine, Hydroxyurea (HU) and various butyrate derivatives (13). HU has shown substantial benefits in a subgroup of patients with sickle cell anemia (14) and in a few pediatric patients with thalassemia where transfusion requirements were generally eliminated after treatment with $\mathrm{HU}$ for $\sim 20$ months $(15,16)$. However, several authors $(13,17)$ reported the role of HU in thalassemia therapy to be rather inconsistent, some showing good responses while others did not $(17,18)$. Further, despite the beneficial effects of HU on erythropoiesis it may be difficult to correct the anemia associated with thalassemia with the use of $\mathrm{HU}$ alone particularly in case of genetic predisposition, such as the presence of Xmnl polymorphism (19) and the type of thalassemia such as hemoglobin E-thalassemia (20). Therefore, importance of proper genetic screening has been emphasized by some authors $(21,22)$.

Recombinant human erythropoietin was employed to achieve the benefit of increasing 'thalassemic erythropoiesis' without raising fetal hemoglobin in $\beta$-thalassemia intermedia who had undergone spleenectomy (23). Recently, the treatment with Darbepoetin- $\alpha$ was reported to increase hemoglobin levels substantially in patients with $\mathrm{HbE} / \beta$-thalassemia disease. However, the search for new compounds that augment fetal hemoglobin production and are non-toxic in nature is still on in in vitro system as well as on various animal models (24-26). Iron overload causes most of the mortality and morbidity associated with thalassemia, and serum ferritin (SF) is most commonly measured as an indicator of iron stores. Ferritin levels below $2500 \mathrm{mg} / \mathrm{ml}$ are associated with improved survival (1), and therefore drugs that are nontoxic but capable of reducing SF level may be useful in thalassemia.

In the present investigation, therefore, homeopathic remedies that generally agreed with the symptoms of thalassemic patients have been administered either singly or in combination depending on changeable symptoms in patients who have been on HU treatment for varying periods of time from a few months to over 6 years. In this investigation, the primary objectives were to examine if the homeopathic remedy, in combination with HU, could bring beneficial effects, as manifested by (i) diminishing SF level, (ii) augmenting $\mathrm{HbF}$ synthesis and (iii) reduction of spleen size in patients with spleenomegaly.

\section{Material and Methods}

\section{Subjects}

This research was conducted in compliance with the protocols of Helsinki Declaration and the Institutional Ethical Committee, University of Kalyani. Informed consents were also obtained from the patients or their parents (of minors), who volunteered to undertake this study. Subjects were examined for their general health and status of their spleen enlargement periodically.

Thirty-eight patients attending the Thalassemia Foundation Clinic at F-44 Footnani Chamber, Corporation Place, Kolkata-700013 from March 2001 to September 2006 had been put on regular HU administration at rates varying 
between $5 \mathrm{mg} / \mathrm{kg} /$ day to a maximum of $20 \mathrm{mg} / \mathrm{kg} /$ day depending on conditions of the patient. Most of these patients were transfusion dependent.

\section{Test protocols used and number of subjects for each protocol}

They were periodically examined for physical conditions of liver and spleen and also for other blood parameters like SF content, fetal hemoglobin ( $\mathrm{HbF}$ ) and hemoglobin $(\mathrm{Hb})$ content before and after administration of $\mathrm{HU}$. Tests were made on an actual cost-no-profit basis only when patient's condition demanded, as most of them were extremely poor, many of them visiting from some other districts like Midnapur, Cooch Behar in West Bengal. The results and number of subjects who provided samples for examination before and after $\mathrm{HU}$ treatment totaled 38, of which 32 belonged to $\mathrm{HbE} / \beta$ type and 6 belonged to $\beta$-thalassemia major type. Of the $32 \mathrm{HbE} / \beta$ patients, the mean values of $\mathrm{SF}$ content of 18 , and $\mathrm{HbF}$ and $\mathrm{Hb}$ contents of all 32 were studied. Of the six $\beta$-major patients, the mean values of SF content of four, $\mathrm{HbF}$ level of three and $\mathrm{Hb}$ content of all six have been obtained. This variation was unavoidable owing to the disapproval of some patients for testing too many blood parameters. Out of the 38 patients who received homeopathic remedies as well as $\mathrm{HU}, 32$ belonged to $\mathrm{HbE} / \beta$ type and six to $\beta$-major type. Out of 32 patients with $\mathrm{HbE} / \beta$ thalassemia, SF level was determined from 20 patients, $\mathrm{HbF}$ from 10, Platelet count (PC) from $27, \mathrm{Hb}$ content from 27, mean corpuscular volume (MCV), mean corpuscular hemoglobin concentration (MCHC), and white blood cell (WBC) count from 27 patients each, bilirubin from 6 , aspartate amino transferase (AST) from 4, alanine amino transferase (ALT) from 4, serum total protein content from 4 and mean corpuscular hemoglobin $(\mathrm{MCH})$ was analyzed from 27 patients.

Out of six $\beta$-major patients, $\mathrm{SF}$ and $\mathrm{HbF}$ level of four subjects, $\mathrm{PC}$ and $\mathrm{Hb}$ content of six, MCV, MCHC and WBC of six patients each, bilirubin, ALT, AST and serum total protein from two subjects each and $\mathrm{MCH}$ from six subjects were considered. Incidentally, the patients showing symptoms of liver disorders and jaundice were subjected to additional tests like AST, ALT and bilirubin.

\section{Age and sex of patients and blood transfusion periods}

The age of these 38 patients ranged between 6 and 25 years, the majority being in 4-10 years' age group. In $\beta$-major group, there was one female and five male subjects. In $\mathrm{HbE} / \beta$ group, there were 20 males and 12 females. Except for three patients, the remaining patients had history of blood transfusion ranging from once in a week to (rarely) once in 6 months.
Span of HU plus homeopathy treatment

The homeopathic treatment started from June 19, 2006 to consecutive batches of patients who visited the clinic till September 23, 2006; and the data of each patient under homeopathic treatment for 3 months for various parameters of study were taken.

\section{Urinary iron excretion}

Initially, the first void urine of 20 patients of $\mathrm{HbE} / \beta$ group was tested for iron contents in urine for 10 consecutive days by method of atomic absorption spectrophotometry (GBC Avanta, Australia) using authentic iron standards. Homeopathic medicines, namely, Pulsatilla-30 (Puls-30), Pulsatila mother tincture (Puls Q), Ferrum Metallicum-30 (Fer Met-30), and Ceanothus 6 (Cean-6) were administered to three, five, three and six patients by following similia principles. Three patients were given placebo. However, their HU treatment was continued as well. The anemic patients (or their parents) did not agree to give their blood samples for 10 consecutive days for obvious reasons, but agreed to give first void urine, for which the data of urinary iron content of them (Fig. 1) could only be analyzed.

\section{Source and Dose of Homeopathic Remedies}

The homeopathic remedies were procured from HAPCO, 165, Bipin Behari Street, Kolkata. The mother tincture of Ceanothus americanus is derived from alcoholic extract of fresh leaves of New Jersey Tea (C. americanus Family: Rhamnaceae) and that of Pulsatilla nigricans is derived from the entire fresh plants $(P$. nigricans; Family: Ranunculaceae) when in flowers (27). Ferrum metallicum is derived from pure metallic iron by procedure of homeopathic potentization (28).

Ten drops of the mother tincture of either Ceanothus or Pulsatilla, prescribed as per simila principle of homeopathy (i.e. taking into consideration guiding symptoms in a holistic manner), were advised to be taken with half cup water twice daily in empty stomach for 3 weeks at a stretch and then withdrawal for a week. The 30th potency (a serial homeopathic dilution of $1 / 10^{60}$ ) of Pulsatilla and Ferrum Met and 6th potency (a dilution of $1 / 10^{12}$ ) of Ceanothus were used; five-six drug soaked globules (No. 20) that formed a single dose, were advised to be taken twice daily for 20 consecutive days and then advised withdrawal for 10 days. The remedies were cyclically repeated in this manner.

\section{Methods}

Five milliliters of blood was drawn from each patient by venipuncture near the arm joint in glass vials containing EDTA (anti-coagulant). Serum was extracted by centrifugation at $1000 \mathrm{~g}$ and by collection of the supernatant. 


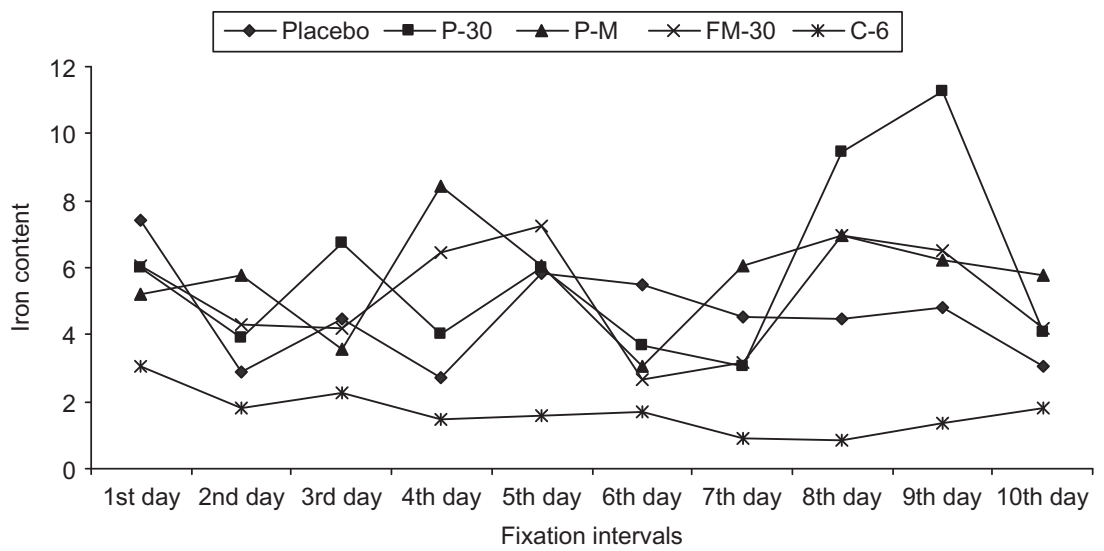

Figure 1. Iron contents of subjects fed with Placebo and Verum continuously for 10 days.

\section{High-performance liquid chromatographic analysis of hemoglobin}

Hemoglobin type $\mathrm{HbF}$ was quantified by automated high-performance liquid chromatography (VARIANT; Bio-Rad, Hercules, CA, USA) (29).

\section{Immunoassay of Ferritin EIA}

Enzyme immunoassay for the quantitative determination of immunoglobulin subclass E (IgE) in human ferritin was made in an ELISA Reader (Biorad, USA) by using the kits from Genix Technology Inc, Canada).

For $\mathrm{Hb}$ analysis, a Cell Counter (Medonic CA 530, E. Merck, Germany) was used by deploying standard kit from E. Merck, Germany.

\section{Total protein, ALT, AST and Bilirubin}

These were recorded by Biochemical Semi auto-analyzer, Microlab 300 (E. Merck, Germany).

\section{Statistical Analysis}

The levels of significance of differences were determined between the data of parameters obtained before the homeopathic drug administration and 3 months after administration of the remedies by Student's ' $t$ ' test method.

\section{Results}

\section{Urinary Iron Excretion Pattern}

A careful analysis of the data (Fig. 1) revealed a relatively low iron content from the first day and showed a wave like curve in Cean-6-fed group. On the other hand, the initial iron contents were recorded to be more in the other drug-fed and placebo-fed series. There was also a wave like fall and rise of iron contents in these groups as well as in the placebo, except for the fact that the Puls30- and Puls-Q-fed group showed relatively more iron excretion. Therefore, there was no clear indication of any definite trend of iron excretion except for the fact that iron excretion appeared to be marginally more in the drug-fed groups (except Cean-6-fed group) and subsequently the three placebo-fed patients were also administered homeopathic remedy as per similia principle. Since the main objective was also to examine if the homeopathic remedy could benefit the patients already on $\mathrm{HU}$ treatment, we did not put any further importance to the placebo-fed control as we considered the HU administration group as our main control to evaluate additional benefit, if any, derived by the administration of homeopathic remedy.

\section{Changes in $\mathrm{SF}, \mathrm{HbF}$ and $\mathrm{Hb}$ Levels After Drug Administration}

There was a decrease of ferritin level and an increase of $\mathrm{HbF}$ content in both $\mathrm{HbE} / \beta$ and $\beta$-major subjects after administration of $\mathrm{HU}$ (Fig. 2A and $\mathrm{B}$ ), although $\mathrm{Hb}$ content in $\mathrm{HbE} / \beta$ group did not appreciably decrease. There was a noticeable decrease in the $\mathrm{Hb}$ content of the $\beta$-major group after administration of $\mathrm{HU}$ for a varying period of time ranging from a therapy for 1-5 years (complete data not shown). There was a significant reduction of SF in the combined treatment $(P<0.001)$ in $\mathrm{HbE} / \beta$ group (Fig. 3A).

Although there was a further reduction in the $\beta$-major group, the decrease was statistically insignificant like that of only HU treatment group. There was also a significant increase $(P<0.05)$ in $\mathrm{HbF}$ level in $\mathrm{HbE} / \beta$ group but in the $\beta$-major group there was actually a decrease in $\mathrm{HbF}$ level (Fig. 3B). The $\mathrm{Hb}$ content in $\mathrm{HbE} / \mathrm{\beta}$ group however, was very marginally reduced, while there was a little increase in $\mathrm{Hb}$ level in the $\beta$-major group (Fig. 3C). 

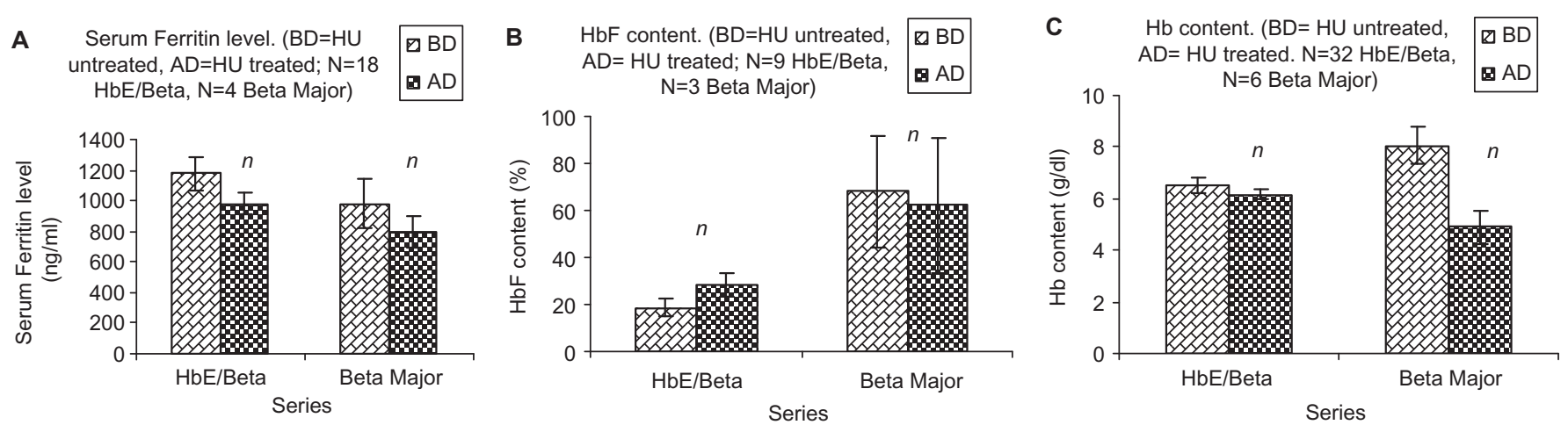

Figure 2. Effect of $\mathrm{HU}$ on thalassemic subjects $(\mathrm{BD}=\mathrm{HU}$ untreated, $\mathrm{AD}=\mathrm{HU}$ treated; $N=$ Number of subjects): (A) $\mathrm{SF}$ level. (B) Fetal hemoglobin $(\mathrm{HbF})$ content. (C) Hemoglobin $(\mathrm{Hb})$ content.

\section{Other Blood Parameters in the Combined Treated Group}

The PC in both $\mathrm{HbE} / \beta$ and $\beta$-major were decreased (Fig. 3D). The $\mathrm{MCV}$ of $\mathrm{Hb} \mathrm{E} / \beta$ group remained more or less the same, while there was a decrease in $\beta$-major group (Fig. 3E), which was statistically insignificant. The MCHC in $\mathrm{HbE} / \beta$ group remained more or less the same, while in $\beta$-major there was a little increase (Fig. 3F). There was also a little increase in $\mathrm{MCH}$ (Fig. $3 \mathrm{G}$ ) of the $\beta$-major group; however, the increase was statistically insignificant. The WBC count in $\mathrm{HbE} / \beta$ was slightly increased while it was marginally decreased in $\beta$-major (Fig. $3 \mathrm{H}$ ). The bilirubin content was same in $\mathrm{HbE} / \beta$ while it was decreased marginally in $\beta$-major group (Fig. 3I). While there was a distinct reduction in the AST (SGOT) level in $\mathrm{Hb} \mathrm{E} / \beta$ group, in $\beta$-major there was only a marginal increase noted, though the level was in the normal range (Fig. 3J). The same was true for ALT (SGPT) level (Fig. 3K), while in $\beta$-major there was palpable change in serum total protein level, there was marginal increase in serum total protein level (Fig. 3L) of $\mathrm{Hb} \mathrm{E} / \beta$ group.

\section{Blood Transfusion Period}

In most cases dependent on blood transfusion, there was an increase in the period of their transfusion demand (ranging between 25 and $75 \%$ ) in the combined treatment group. In two cases, patients used to have fever, before and after transfusion, but after administration of homeopathic remedies on similia principle for 3 months, the incidence of fever disappeared.

\section{Spleen Size and General Health}

In the 30 patients having enlarged spleen of varying lengths (total $125 \mathrm{~cm}$ ) before administration of homeopathic remedy, there was a distinct reduction in length (total $45 \mathrm{~cm}$ ); as many as 11 of them showed no palpable enlarged spleen after homeopathic treatment. The general health and spirits of the patients appeared to have improved after this combined treatment in the majority of the cases studied.

\section{Discussion}

In the present investigation, out of a total of 38 patients, 6 belonging to thalassemia major type ( $\beta$-thalassemia) and 32 to $\mathrm{HbE} / \beta$ type, the greater majority showed positive response to combined homeopathic therapy. There was a significant increase in induction of $\mathrm{HbF}$ in them, which is very encouraging. In fact, augmentation of fetal hemoglobin $(\mathrm{HbF})$ synthesis is highly solicited in thalassemic patients as high levels of fetal hemoglobin production can ameliorate sickle cell disease and $\beta$-thalassemia (30). Incidentally, oral administration of $\mathrm{HU}$ alone has been reported to increase the level of $\mathrm{HbF}$ in both thalassemia major and thalassemia intermedia patients, with varying degree of response, presumably because of the molecular heterogeneity of the $\beta$-globin gene in major $\beta$-thalassemia and the complexity of interacting genetic factors involved in $\mathrm{HbF}$ switching in each respective patient (31). In fact, among the various drugs recently proposed to improve the clinical conditions in both sickle cell disease and $\beta$-thalassemia (20,32-36), HU was stated to be the most effective. In the present study, a noticeable increase in $\mathrm{HbF}$ was also noted in patients receiving $\mathrm{HU}$ alone, but there was further increase of $\mathrm{HbF}$ level in patients receiving the combined homeopathic treatment, thereby showing additional beneficial effect of homeopathy. However, effect on individual patients in regard to increase in $\mathrm{HbF}$ was variable (data not shown) as also reported in the other study (13). In case of $\mathrm{Hb}$, in the only HU-treated subjects, there was a considerable decrease of $\mathrm{Hb}$ content in the $\beta$-major group, but there was actually a little increase in the combined treated group. Therefore, on the whole, there appeared to be additional benefit of homeopathic drug in terms of both $\mathrm{HbF}$ and $\mathrm{Hb}$ contents. It is suggested that $\mathrm{HU}$ produces fetal hemoglobin via reactivation of gamma genes through some unknown 
A Serum ferritin content. $(B D=H U \square B D$

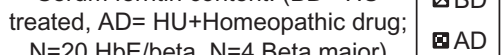

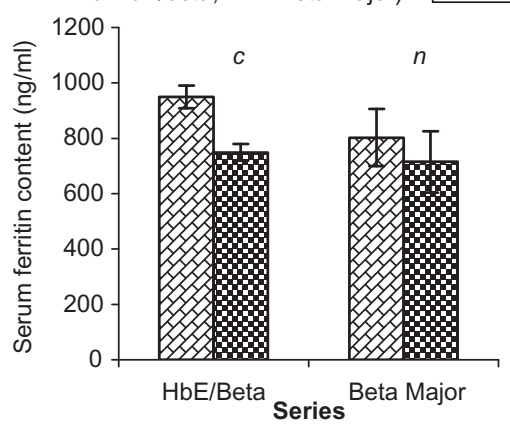

D Platelet count $(B D=H U$ treated, $A D=\square B D$ $\mathrm{HU}+$ Homeopathic drug; $\mathrm{N}=27 \mathrm{HbE} /$ beta, $\mathrm{N}=6$ Beta major)

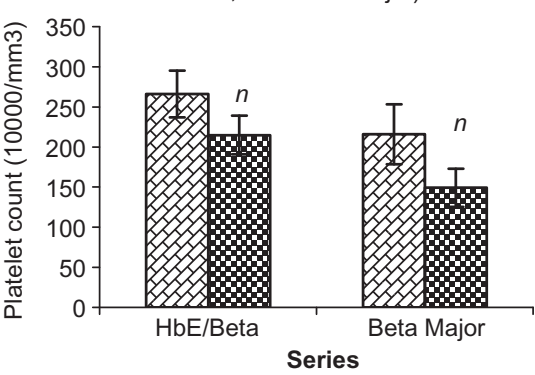

G $\mathrm{MCH}(\mathrm{BD}=\mathrm{HU}$ treated, $\mathrm{AD}=$ HU+Homeopathic drug; $\mathrm{N}=27 \mathrm{HbE} /$ beta, $\mathrm{N}=6$ Beta major) $\mathrm{OAD}$

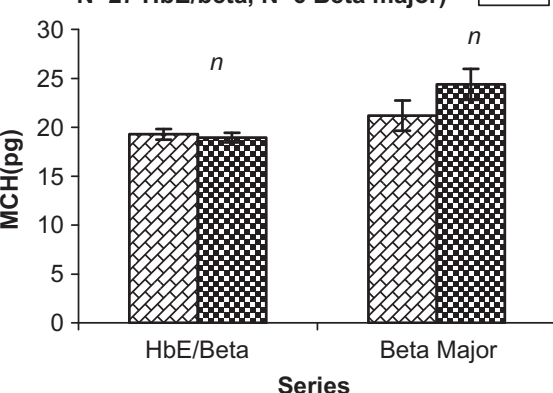

J AST level $(B D=H U$ treated, $A D=\square B D$ $\mathrm{HU}+\mathrm{Homeopathic} \mathrm{drug;}$ $\mathrm{N}=4 \mathrm{HbE} /$ beta, $\mathrm{N}=2$ Beta major) $\mathrm{QAD}$

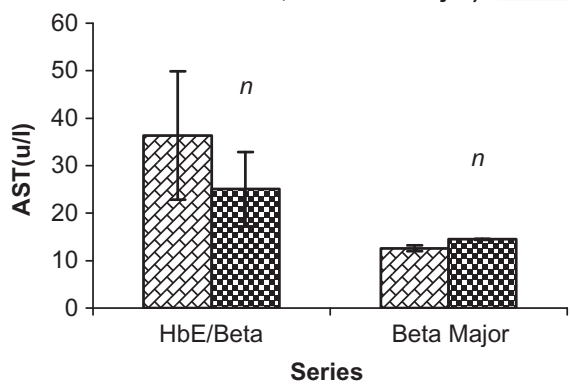

( $a=p<0.05 ; b=p<0.01 ; c=p<0.001 ; n=$ non-significant)
B

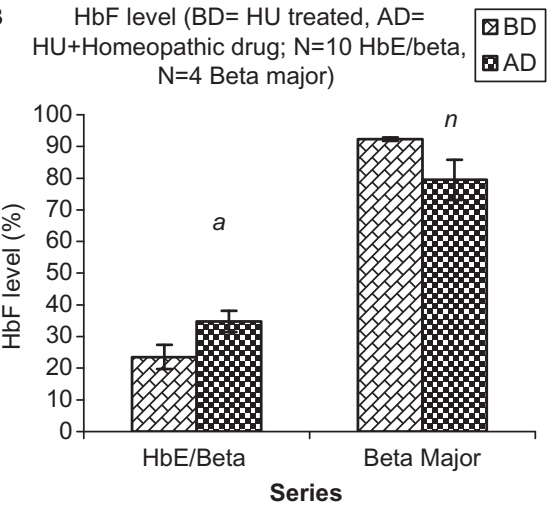

E

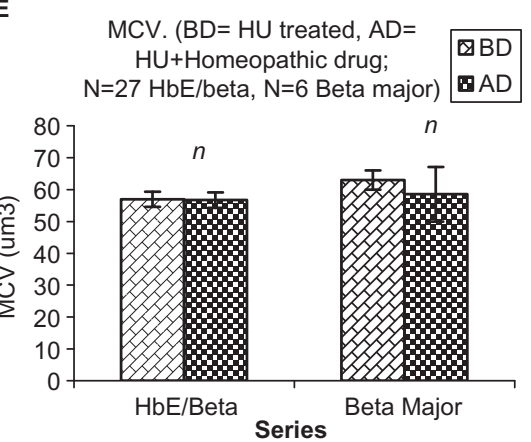

H WBC count $(B D=H U$ treated, $A D=\square B D$ HU+Homeopathic drug; $\mathrm{N}=27 \mathrm{HbE} /$ beta, $\mathrm{N}=6$ Beta major) $\mathrm{BAD}$

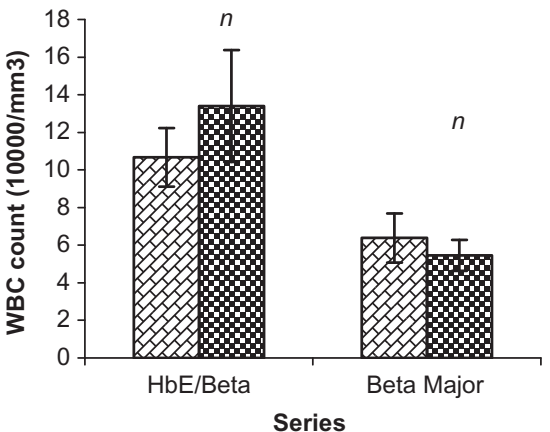

K ALT level $(B D=H U$ treated, $A D=$ $\mathrm{HU}+\mathrm{Homeopathic} \mathrm{drug;}$ $\mathrm{N}=4 \mathrm{HbE} /$ beta, $\mathrm{N}=2$ Beta major)

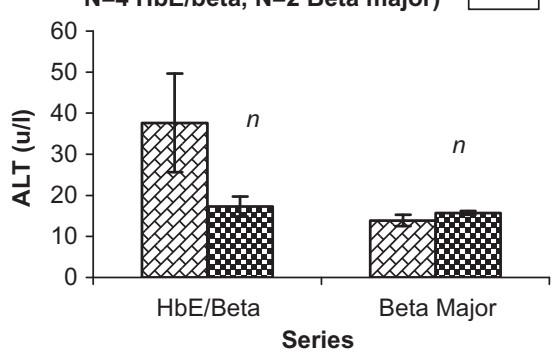

C

$\mathrm{Hb}$ content $(\mathrm{BD}=\mathrm{HU}$ treated, $\mathrm{AD}=$ $\mathrm{HU}+\mathrm{Homeopathic} \mathrm{drug;}$ 曰BD $\mathrm{N}=27 \mathrm{HbE} /$ beta, $\mathrm{N}=6$ Beta major) $\mathrm{GAD}$

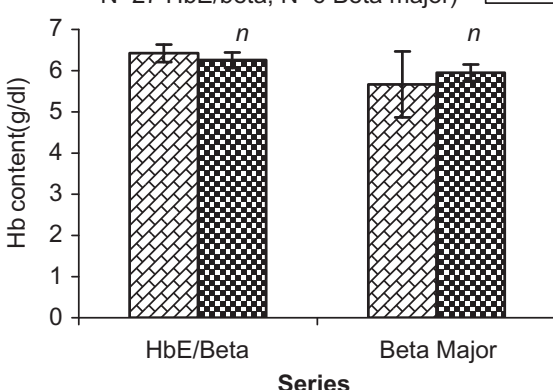

$\mathbf{F}$

$\mathrm{MCHC} .(\mathrm{BD}=\mathrm{HU}$ treated, $\mathrm{AD}=$ $\mathrm{HU}+$ Homeopathic drug; $\mathrm{N}=27 \mathrm{HbE} /$ beta,
$\mathrm{N}=6$ Beta major)

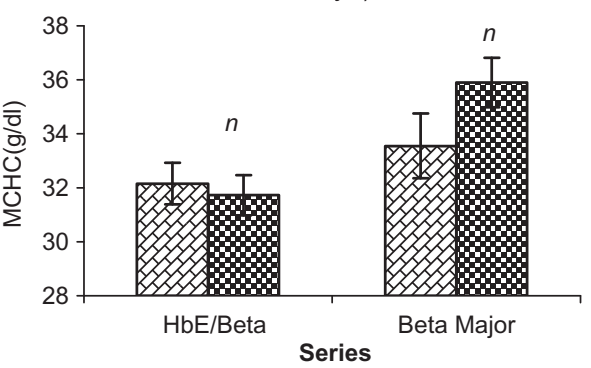

I Bilirubin content $(B D=\mathrm{HU}$ treated, $\square \mathrm{BD}$ $A D=\mathrm{HU}+$ Homeopathic drug; $\mathrm{N}=6 \mathrm{HbE} / \mathrm{beta}, \mathrm{N}=2$ Beta major)
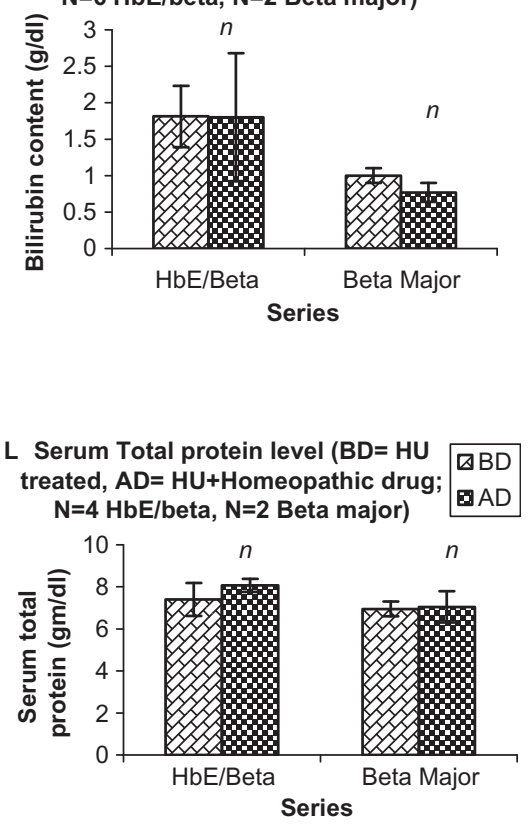

Figure 3. Comparative efficacy of only HU (BD) treatment and HU plus homeopathic drug (AD) treatment on thalassemic subjects: (A) SF level. (B) HbF content. (C) Hb content. (D) PC. (E) MCV. (F) MCHC. (G) MCH. (H) WBC Count. (I) Bilirubin content. (J) AST level. (K) ALT level. (L) Serum total protein level. 
molecular mechanism (37). These authors also reported promising results of $\mathrm{HU}$ therapy in thalassemia intermedia.

But there are reports in which some patients exhibited insignificant or no change in $\mathrm{HbF}$ levels after $\mathrm{HU}$ treatment $(20,33)$. Nevertheless, HU therapy has been termed as the most promising therapy because of the oral route of administration, for being relatively inexpensive and with no or little side effects (37). Therefore, if the induction of $\mathrm{HbF}$ level could be further accelerated or rejuvenated, as the homeopathic therapy appeared to produce, could be of additional benefit to the patients. The advantages of the homeopathic remedies are manifold. They are also inexpensive, easily available, taken in micro doses and without any known side-effects.

How the homeopathic remedies could bring forth such positive changes remains unclear. But the present results would also lend support to the contention (38-40) that the potentized homeopathic remedies possibly acted through regulation of specific and relevant gene expression responsible for the apparently enhanced synthesis of the $\mathrm{HbF}$ and decrease of ferritin level. While in the advanced countries the treatment and management strategies have made significant progress in the reduction of thalassemia to a great extent, such treatment strategies are beyond reach of the poor patients inhabiting developing countries. Incidentally, homeopathic remedies also showed considerable potentials to ameliorate arsenicosis (41-43), a burning public health problem of arsenic exposure through groundwater contamination in some third world countries, because only limited success could so far be achieved with the orthodox medicine tested to cure arsenicosis. Therefore, the initial results of the present study are very encouraging and need further trial by other researchers independently to verify and confirm (or refute) our findings. Further works involving additional important parameters are presently in progress.

\section{Acknowledgement}

Part of the study was financially supported by a research grant to A.R.K.B. from Boiron Laboratory, Lyon, France.

\section{References}

1. Rund D, Rachmilewitz E. $\beta$-Thalassemia. $N$ Engl $J$ Med 2005;353:1135-46.

2. Cunningham MJ, Macklin EA, Neufeld EJ, Cohen AR. Complications of $\beta$-thalassemia major in North America. Blood 2004;104:34-9.

3. Higgs DR, Thein SL, Woods WG. The pathophysiology of the thalassemias. In: Weatherall DJ, Clegg B (eds). The Thalassemia Syndromes, 4th edn. Oxford, England: Blackwell Science, 2001, $133-91$.

4. Hoffbrand AV, Cohen A, Hershko C. Role of deferiprone in chelation therapy for transfusional iron overload. Blood $2003 ; 102: 17-24$.
5. Borgna-Pignatti C, Rugolotto S, De Stefano $P$, Zhao H, Cappellini MD, Del Vecchio GC, et al. Survival and complications in patients with thalassemia major treated with transfusion and deferoxamine. Haematologica 2004;89:1187-93.

6. Wanless IR, Sweeney G, Dhillon AP, Guido M, Pig A, Galanello R, et al. Lack of progressive hepatic fibrosis during long-term therapy with deferiprone in subjects with transfusiondependent $\beta$-thalassemia. Blood 2003;101:2460.

7. Ceci A, Baiardi P, Felisi M, Capellini MD, Carnelli V, De Sanctis V, et al. The safety and effectiveness of deferiprone in a large-scale, 3-year study in Italian patients. $\mathrm{Br} J$ Haematol 2002;118:330-6.

8. Piga A, Gaglioti C, Fogliacco E, Tricta F. Comparative effects of deferiprone and deferoxamine on survival and cardiac disease in patients with thalassemia major: a retrospective analysis. Haematologica 2003;88:489-96.

9. Hershko C, Link GM, Konijn AM, Cabantchik ZI. Iron chelation therapy. Curr Hematol Rep 2005;4:110-6.

10. Anderson LJ, Wonke B, Precott E, Holden S, Walker JM, Pennell DJ. Comparison of effects of oral deferiprone and subcutaneous desferrioxamine on myocardial iron concentrations and ventricular function in beta-thalassemia. Lancet 2002;360:516-20.

11. Cohen AR, Galanello R, Pannell DJ, Cunningham MJ, Vichinsky E. Thalassemia. Hematology (Am Soc Hematol Educ Program) 2004;1:14-34.

12. Gallo E, Massero P, Miniero R, David D, Tarella C. The importance of the clinical and hematological features of thalassemia intermedia. Blood 1979;41:211-21.

13. Atweh GF, Loukopoulos D. Pharmacological induction of fetal hemoglobin in sickle cell disease and $\beta$-thalassemia. Semin Hematol 2001;38:367-73.

14. Steinberg $\mathrm{MH}$, Barton F, Castro O, Pegelow $\mathrm{CH}$, Ballas SK, Kutlar A, et al. Effect of hydroxyurea on mortality and morbidity in adult sickle cell anemia: risks and benefits up to 9 years of treatment. JAMA 2003;290:756.

15. Bradai M, Abad MT, Pissard S, Lamraoui F, Skopinski L, Montalembert MD. Hydroxyurea can eliminate transfusion requirements in children with severe $\beta$ thalassemia. Blood 2003;102:1529-30.

16. Sylvia ST, Kuypers FA, Olivieri NF, Weatherall DJ, Mignacca R, Coates TD, et al. Single and combination drug therapy for fetal hemoglobin augmentation in hemoglobin $\mathrm{E} / \beta^{0}$ thalassemia: Considerations for treatment. Ann N Y Acad Sci 2005;1054:250-6.

17. Watanapokasin Y, Chuncharunee S, Sanmund D, Kongnium W, Wnichagoon P, Rodgers GP, et al. In vivo and intro studies of fetal hemoglobin induction by hydroxyurea in $\beta$ thalassemia/hemoglobin E patients. Exp Hematol 2005;33:1486-92.

18. Yavarian M, Karimi M, Bakker E, Harteveld CL, Giordano PC. Response to hydroxyurea treatment in Iranian transfusiondependent $\beta$ thalassemia patients. Haematologica 2004;89:1172-8.

19. Gilman JG, Huisman TH. DNA sequence variation associated with elevated fetal G gamma globin production. Blood 1985;66:783-7.

20. Fucharoen S, Siritanaratkul N, Winichagoon P, Gowthaworn J, Siriboon W, Maaungsup W, et al. Hydroxyurea increases hemoglobin $\mathrm{F}$ levels and improves the effectiveness of erythropoiesis in $\beta$-thalassemia/Hemoglobin E disease. Blood 1996;87:877-92.

21. Alebouyeh M, Moussavi F, Haddad-Deylami H, Vossough P. Hydroxyurea in the treatment of major $\beta$ thalassemia and importance of genetic screening. Ann Hematol 2004;83:430-3.

22. Watanapokasin R, Sanmund D, Wnichagoon P, Muta Koichiro, Fuchareon S. Hydroxyurea responses and fetal hemoglobin induction in $\beta$ thalassemia/Hb E patients peripheral blood erythroid cell culture. Ann Hematol 2006;85:164-9.

23. Rachmilewitz EA, Aker M, Perry D, Dover G. Sustained increase in hemoglobin and RBC following long-term administration of recombinant human erythropoietin to patients with homozygous $\beta$ thalassemia. Br J Haematol 1995;90:341-5.

24. Fibach E. Cell culture and animal models to screen for promising fetal hemoglobin-stimulating compounds. Semin Haematol 2001;38:374-81.

25. Oliveiri NF, Rees DC, Ginder GD, Thein SL, Wayne JS, Chang L, et al. Elimination of transfusions through induction of fetal hemoglobin synthesis in Colley's anemia. Ann N Y Acad Sci 1998;850:100-9. 
26. Perrine SP. Fetal globin induction-can it cure $\beta$ thalassemia? Hematology 2005;38-44.

27. Clarke JH. A Dictionary of Practical Materia Medica, Vol. III. New Delhi, India: B. Jain Publishers (P) Ltd, 2003.

28. Choudhuri NM. A Study on Materia Medica. New Delhi, India: B. Jain Publishers (P) Ltd, 1999.

29. Fuchareon S, Winichagoon P, Wisedpanichikij R, Sae-Ngow B, Sriphanich R, Oncoung W, et al. Prenatal and postnatal diagnoses of thalassemias and hemoglobinopathies by HPLC. Clin Chem 1998:44:740-8.

30. Oliveiri NF, Weatheral DJ. The therapeutic reactivation of fetal haemoglobin. Hum Mol Genet 1998;7:1655-8.

31. Cao A, Gatanello R, Rosatelli MC. Genotype-phenotype correlations in $\beta$-thalasemia. Blood Rev 1994;8:1-12.

32. Charache S, Terrin ML, Moore RD, Dover GJ, Barton FB, Eckert SV, et al. Effect of hydroxyurea on the frequency of painful crises in sickle cell anemia. $N$ Engl J Med 1995;332:1317-22.

33. Olivieri NF. Reactivation of fetal hemoglobin in patients with beta thalassemia. Semin Hematol 1996;33:24-42.

34. Veith R, Galanello R, Papayannopoulou G, Stamatoyannopoulos G. Stimulation of F-cell production patients with sickle cell anemia treated with cytarabine or hydroxyurea. $N$ Engl J Med 1985;313:1571-5.

35. Maier-Redeiersperger M, De Montalembert M, Flahault A, Neonato MG, Ducrocq R, Masson MP. Fetal hemoglobin and Fcell responses to long-term hydroxyurea treatment in young sickle cell patients. Blood 1998;91:4472-9.

36. Hajjar FM, Pearson HA. Pharmacologic treatment of thalassemia intermedia with hydroxyurea. J Pediatr 1994;125:490-2.
37. Dixit A, Chatterjee TC, Mishra P, Choudhury DR, Mahapatra M, Tyagi $\mathrm{S}$, et al. Hydroxyurea in thalassemia intermedia-a promising therapy. Ann Hematol 2005;84:441-6.

38. Khuda-Bukhsh AR. Potentized homeopathic drugs act through regulation of gene-expression: a hypothesis to explain their mechanism and pathways of action in vivo. Comp Ther Med 1997:5:43-6.

39. Khuda-Bukhsh AR. Towards understanding molecular mechanisms of action of homeopathic drug: an overview. Mol Cell Biochem $2003 ; 253: 339-45$

40. Khuda-Bukhsh AR. Laboratory research in homeopathy: pro. Integr Cancer Ther 2006;5:320-32.

41. Khuda Bukhsh AR, Pathak S, Guha B, Roy Karmakar S, Das JK, Banerjee $\mathrm{P}$, et al. Can homeopathic arsenic remedy combat arsenic poisoning in human exposed to ground water arsenic contamination: a preliminary report on first human trial. Evid Based Complement Alternat Med 2005;2:537-48.

42. Belon P, Banerjee P, Chaki Choudhury S, Banerjee A, Biswas SJ, Roy Karmakar S, et al. Can administration of potentized homeopathic remedy, Arsenicum Album, alter anti-nuclear antibody (ANA) titer in people living in high risk arsenic contaminated areas?: I. A correlation with certain hematological parameters. Evid Based Complement Alternat Med 2006;3:99-107.

43. Belon P, Banerjee A, Roy Karmakar S, Biswas SJ, Chaki Choudhury S, Banerjee P, et al. Homeopathic remedy for arsenic toxicity?: Evidence-based findings from a randomized placebo controlled double blind human trial. Sci Tot Environ 2007; DOI: 10.1016/j.scitotenv.06.001.

Received May 9, 2007; accepted September 5, 2007 


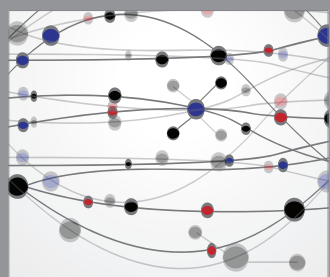

The Scientific World Journal
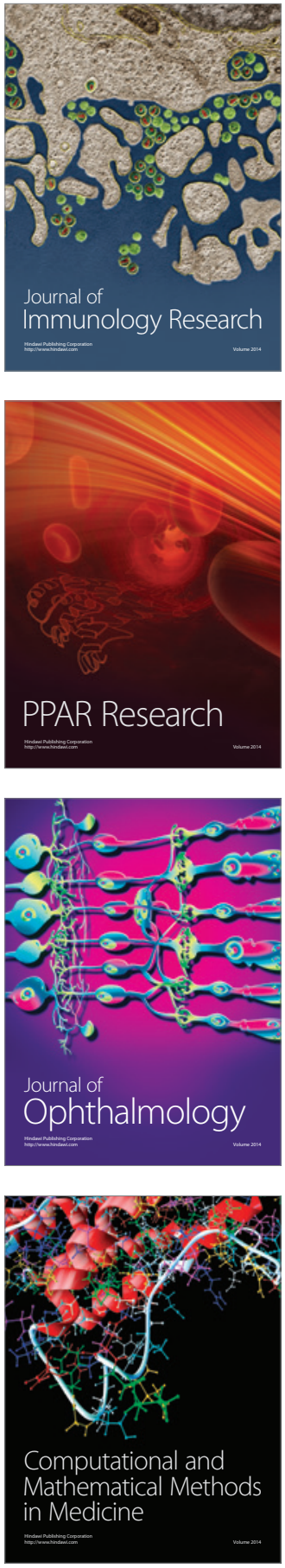

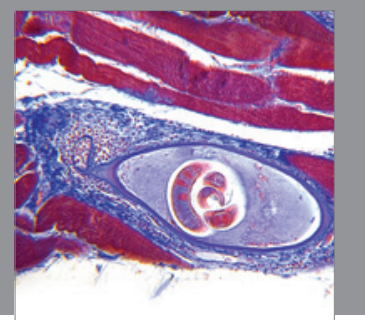

Gastroenterology

Research and Practice
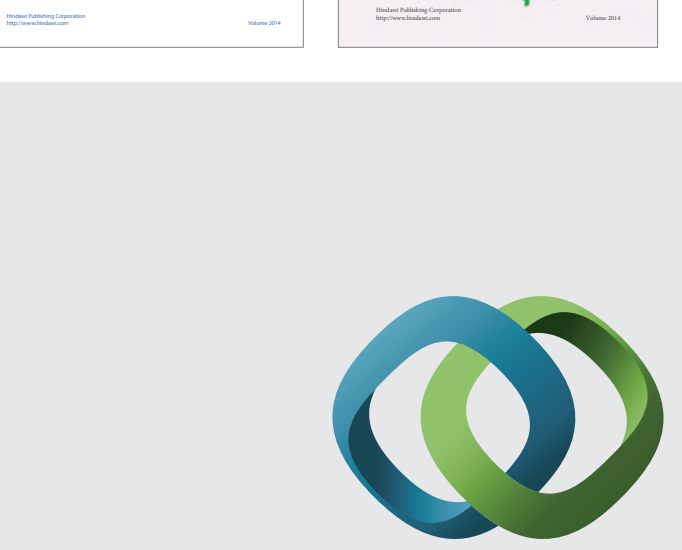

\section{Hindawi}

Submit your manuscripts at

http://www.hindawi.com
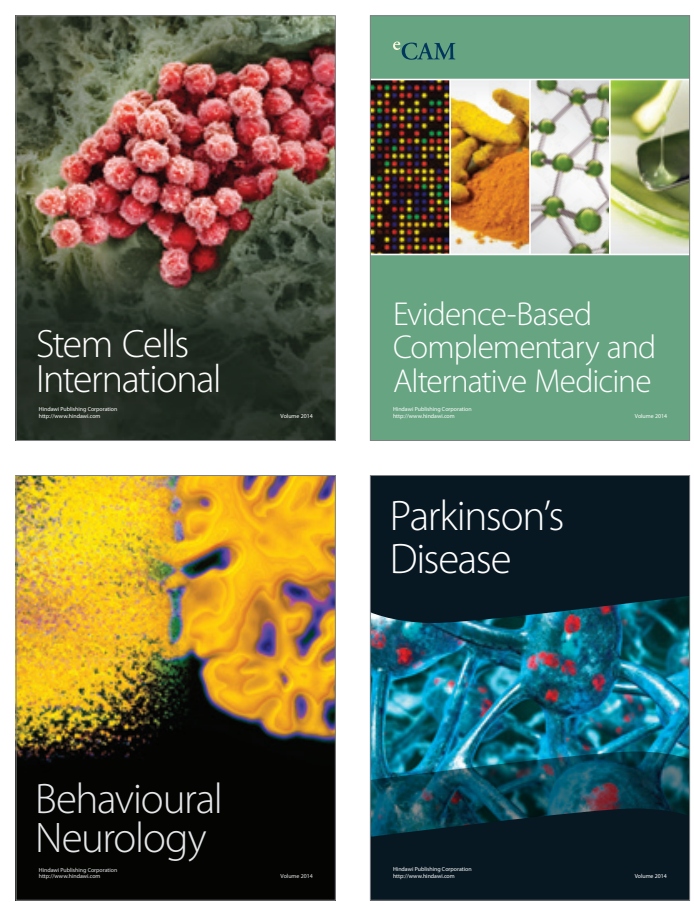

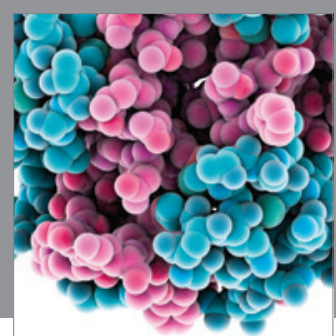

Journal of
Diabetes Research

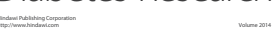

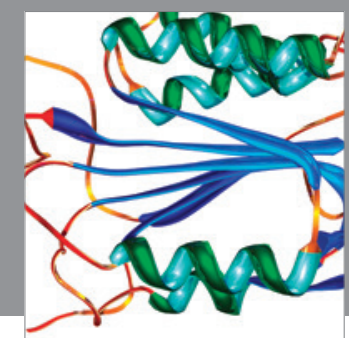

Disease Markers
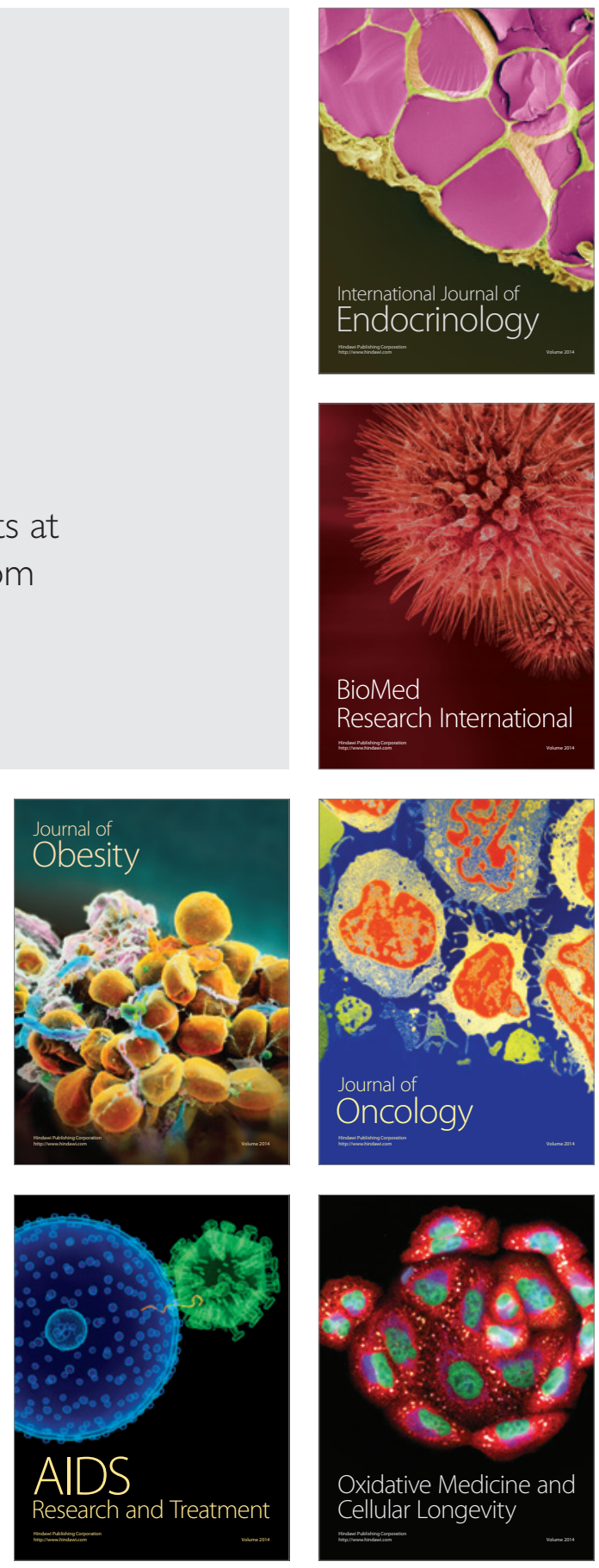